\title{
What Good Is Growth? Reconsidering Dewey on the Ends of Education
}

\section{R. W. Hildreth}

\begin{abstract}
One of the most persistent criticisms of John Dewey is his failure to provide definite ends for education. This essay reconstructs Dewey's educational thought to provide more guidance on the nature of educational ends. Rather than impose external ends and a rigid curriculum, Dewey provides evaluative criteria so that citizens themselves can assess the educational and democratic value of any practice, curricula, or institution. The political implications of this position are profound. It pushes away from expert-driven models of educational authority and towards empirically grounded deliberative processes to guide educational practice and policy.
\end{abstract}

\section{Introduction}

Dewey famously argues that the end of education is growth. This basic idea, widely criticized and often misunderstood, rests on a series of more complex arguments about the nature of education, human experience, and social life. First, Dewey understands education as the reconstruction of experience. As such, there is an intimate and inextricable relation between a person's life experiences on one side and educational methods, content, and ends on the other. We learn by gaining a better sense of the meaning of present experiences and by increasing our ability to direct future experiences (MW 9: 83). Second, we grow when learning opens up opportunities for future growth and thereby enables us to continue our education (MW 9: 107). In this sense, there are no ends outside of the processes of education; it is its own end (MW 9: 54). Third, as a result, Dewey consistently rejects any move to impose ultimate or external ends for education. To do so would violate Dewey's experiential conception of education. ${ }^{1}$ 
The idea that the end of education is growth provokes scorn from radically different perspectives. At one extreme are writers like E. D. Hirsch (1996, 1987), Allan Bloom (1987), and Diane Ravitch (2001, 2000), who argue that Dewey's lack of ends eviscerates the content of "core knowledge" and fragments any sense of coherence in curriculum. The result of progressive reforms, according to Hirsch (1996), has been widespread cultural illiteracy; this illiteracy is a particular problem for civic life in that students lack the core common knowledge to have an "effective national conversation" (xi). At the other end of the spectrum are critical educational theorists like Samuel Bowles and Herbert Gintis (1976), who argue that contemporary educational systems produce docile subjects. They call for education that encourages critical independent thinking in order to challenge existing social structures and norms (see also Freire, 1970; Feinberg and Rosemont, 1975). Bowles and Gintis (1976) criticize Dewey and progressive education for not interrogating the role that schools play in reproducing dominant relations of capitalist production. The shortcoming of Dewey's approach is that "the problem, clearly, is to fix up the people, not change the economic structures which regulate their lives" (p. 26). In this vein, they see little critical traction in Dewey's educational thought. For these critics, progressive education does not lead students to question the status quo nor encourage schools to question their roles in perpetuating the current social order. At the most basic level, each position is uncomfortable with Dewey's claim that "growth itself is the only moral 'end"' (MW 12: 181). Taken together, critics argue that Dewey's educational vision is confused and confusing. Growth, they argue, provides little guidance on how to construct educational goals or structure a curriculum.

Although Dewey directly addressed this question and many other people have come to his defense, this line of criticism has had a curious staying power (see Dewey, LW 13: 7-11, 48-63; Hook, 1949, 1957, 1985a; see also Kliebard, 1995; Suppes, 1996). In a very important sense, this line of criticism is valid. Dewey steadfastly refused to provide an ultimate end for education. He maintained that there are no ends that transcend the specific practices and contexts of education. Despite this argument, I believe we can reconstruct Dewey's educational thought to provide clearer guideposts on the ends of education. Rather than impose specific curricular aims, Dewey provides evaluative criteria so that citizens themselves can assess the educational and democratic value of any practice, curricula or institution. This stance is at the heart of Dewey's radicalism and antifoundationalism; it is also the source of considerable critique. Many commentators are not comfortable with his radical belief that "ordinary" educational actors (students, parents, teachers, administrators) have the capacity to determine their own ends. The political implications of this position are profound. It pushes away from expert driven models of educational authority towards empirically grounded deliberative processes that might guide educational practice and policy.

I believe this is an important time to return to Dewey precisely because recent policy shifts have directed our attention away from these deliberative processes. In 
a variety of ways, education policy has become motivated by increasingly specificand technocratic - aims of academic achievement. These shifts have been widely documented. The No Child Left Behind Act (NCLB), in a variety of ways, urged states and localities to define specific ends - and measurable targets-for student achievement. Critics such as Rothstein and Jacobsen (2006) argue that this definition of student achievement is overly narrow. Other critics have argued that it has created misguided and counterproductive testing policies (Menken, 2006; McNeil, 2005). In fact, the end of improving test scores has created perverse incentives for educational policy; fifteen states have lowered standards in order to achieve goals for proficiency (Bandeira de Mello, Blankenship, \& McLaughlin, 2009, p. vi-viii). While researchers have long documented the deleterious effects of these reforms, Diane Ravitch, as an early advocate and now critic of NCLB, has focused new attention on the narrowing purposes of education. In her recent critical assessment of these reforms, she writes, "testing, I realized with dismay, had become a central preoccupation in the schools and was not just a measure but an end in itself" (2010a, p. 12).

Moreover, increasingly narrow and standardized measures of academic achievement have been paired with increasingly privatized and expert-driven school governance. Charter schools, while publicly financed, famously trade increased autonomy for increased accountability. In exchange for meeting definitive academic targets, independent groups can create schools removed from district bureaucracy and oversight. Increasingly specific curricular missions appeal to particular students and families, positioning citizens as consumers who can choose-or exitschools on the basis of pre-existing preferences (Wilson, 2010). Small school reform efforts (Ancess \& Allen, 2006; Ready \& Lee, 2008) and "portfolio" models of school management (Bulkley \& Henig, 2010) have translated many of these assumptions to district levels. And, as Ravitch (2010b) argues, these reform models are increasingly distanced from democratic governance and deliberation. In this sense, recent policy supports a variety of means to reach ends that are increasingly not open for debate, revision, or deliberation. In contrast, educational ends-viewed in terms of academic achievement-are understood to be self-evident and non-negotiable. These policy shifts have created an atmosphere of increased achievement by any means necessary, including market-based competition between schools and rote methods that "teach to the test."

In this essay, I argue that Dewey's understanding of ends provides critical resources to help us both understand and respond to the increasingly narrow and technical focus of education practice and policy. To make good on this argument, it is necessary to reconstruct his understanding of the ends of education, and to respond to the widely held belief that growth offers little practical guidance for educators and policymakers. My reconstruction proceeds in four steps: in the second section, I review Richard Hofstadter's critique of Dewey. I discuss Dewey's general treatment of educational ends in Democracy and Education in the third section. I then turn, in the fourth section, to a discussion of how these general ends can be applied to specific goals dealing with work and citizenship. In the fifth and concluding 
section, I return to Hostadter's critique as well as discuss the political implications of emphasizing evaluative criteria rather than ends. I argue that Dewey provides a revitalized sense of the importance of democratic deliberation about the proper ends of education at all levels of practice.

\section{Hofstadter's Critique}

The claims of Bloom, Hirsch, and Ravitch were preceded decades earlier by Richard Hofstadter's (1963) compelling critique in Anti-Intellectualism in American Life. I focus on Hofstadter for several reasons: first, he is a canonic source for later critics of Dewey; second, and more importantly, I believe he presents one of the more careful and nuanced criticisms of Dewey. He recognizes Dewey's contributions, but sharply criticizes the implications and consequences of his educational thought. Even though Hofstadter's real target is progressive education, he criticizes Dewey for the role that his thinking played in that movement. In effect, Dewey's arguments were too easily misunderstood, and too easily applied to justify a wide variety of anti-intellectual educational reforms.

While critical, Hofstadter also notes how "progressive education" made important contributions to educational methods-ending the domination of rote instruction, for instance. The problem with progressive education is that it remained confused about, and unable to define, appropriate ends for education (Hofstadter, 1963, p. 375). It is important to note that his argument is directed against both Dewey and the "perversion of his ideas" by advocates of progressive education. For Hofstadter, progressive education dissolved the content of curriculum, thereby contributing to the pervasive trend of anti-intellectualism in America. Part of addressing this critique, then, involves answering the question: is it fair to hold Dewey accountable for the perversion of his ideas? Hofstadter does not blame Dewey for anti-intellectualism; he correctly recognizes that one of Dewey's central aims was to increase the level of intelligence in public life. However, he does criticize Dewey's inability to consider the implications or limits of his ideas.

For Hofstadter, this inattention to implications or limits is compounded by Dewey's inability to present his ideas clearly. This defect contributes to wide misunderstanding and misappropriation. The first problem is Dewey's writing. Hofstadter states, "Dewey wrote a prose of terrible vagueness and plasticity ... His style is suggestive of the cannonading of distant armies: one concludes that something portentous is going on at a remote and inaccessible distance, but one cannot determine just what it is" (p. 361). But more than just a matter of bad writing, Hofstadter continues, "serious faults in style are rarely, if ever, matters of 'mere' style; they embody real differences in conception" (p. 361). Dewey's tendency to be misinterpreted, for Hofstadter, while exacerbated by his writing style, is actually the result of significant gaps in his thought and problems in his logic. And this is a serious charge and deserves our attention. If Dewey indeed failed to make his ideas clear, he opens himself up to misappropriation. 
Hofstadter claims that the main defect in Dewey's educational thought is making growth the very essence and only end of education (p. 373; see also Kandel, 1943). Dewey's idea of growth then becomes the source of endless difficulties for educational theory and practice. Growth, according to Hofstadter, is an inappropriate metaphor for education. Growth is a natural, genetic, and most importantly, automatic process; people do not have control over the way that they grow. In other words, growth is something that happens to us; we do not decide where and how we want to grow. In this, Hofstadter claims that Dewey ignores his own imperative that education is a social and reconstructed process. In positing growth, Dewey, in effect, abdicates any responsibility to determine the ends for education and social life.

For Hofstadter, not only does Dewey provide a bad metaphor for education, but he also takes a worse step in conflating education with growth. That is, Dewey does not simply compare education with growth; for him, education is growth, growth is life, and life is development. Hofstadter (1963) quotes the following passage from Democracy and Education:

We have been occupied with the conditions and implications of growth... When it is said that education is development, everything depends on how development is conceived. Our net conclusion is that life is development, and that developing, growing, is life. Translated into its educational equivalents, this means ( $i$ ) that the educational process has no end beyond itself; it is its own end; and that (ii) the educational process is one of continual reorganizing, reconstructing, transforming. (p. 372; quoting MW 9: 54)

For Hofstadter, if growth was simply a metaphor for education, society could still retain control over the ends, direction, and outcomes of that method or approach. But by equating education and growth, the growth of the child becomes more important than the traditions of society. The historical effect (and subsequent perversion) of this idea is to set up the child's interests (as growth) over and above society. Hofstadter acknowledges that Dewey never, in fact, argued for this. However, "the idea of growth invited educational thinkers to set up an invidious contrast between self-determining, self-directed growth from within, which was good, and molding from without, which was bad" (p. 373). The historical effect of this line of thinking, according to Hofstadter, "was to exalt the child and dismiss the problem of society, on the ground that the growth of the child stood for health, whereas the traditions of society (including curricular traditions) stood for outworn, excessively authoritative demands" (p. 374).

Hofstadter argues that establishing growth as the only end of education makes it impossible to construct a coherent curriculum. Dewey's insistence on concrete situations as the proper starting points for study means that "the kind of long-range evaluation of subjects which is necessary to the design of curricula becomes inordinately difficult" (p. 376). For Hofstadter, this difficulty-while not desirable in elementary school-becomes disastrous in the upper grades. Distinct studies need to be mastered, and mastery comes at the expense of connections to individual in- 
terest and possibly other subjects. For example, Hofstadter might argue that it is not possible to teach high school chemistry based on students' experiences. Rather, it requires focused attention to a distinct subject and development of cumulative lessons of increasing complexity over time.

This idea of growth is also at odds with Dewey's earlier writings in which he argues that education should be the "fundamental method of social progress" (EW 5: 93). ${ }^{2}$ In this idea of progressive growth and change, the individual and social dimensions of education are synthesized: schools become agents of change by educating individuals to be critical inquirers and social actors. Hofstadter argues that Dewey cannot have it both ways. Dewey either has to "sacrifice the ideal of education as growth or abandon the goal of 'forming minds' in accordance with adult, and hence externally imposed, vision of the good society" (1963, p. 379; see also Cunningham, 1994). ${ }^{3}$

In sum, Hofstadter raises important concerns about Dewey's educational thought. In particular, he questions whether Dewey provides definite ends, useful criteria, and substantive curricula. While I will directly address his critique later in the essay, a few points are worth foreshadowing. While Dewey indeed does not prescribe a set curriculum; he does, however, model the process of curricular decision making by offering a sustained discussion of the role and sequence of various subjects: history, science, geography, mathematics, and so on. In response to the criticism that Dewey cannot have it both ways, we need to remember that ends are not imposed by adults in pursuit of social progress, but are the products of democratic deliberations at all levels of educational life (home, classroom, school, district, state, nation, etc.). He attempts to provide guidance for these deliberations with his vision of democratic education. In this sense, the more difficult question is whether Dewey provides sufficient guidance for educators and citizens to determine their own ends. For instance, we still need to ask: Does Dewey's approach ask too much of students, parents, teachers, administrators, or the general public? If so, how much of Hofstadter's critique might still be salient?

\section{General Aims of Education}

For Dewey, the ends and the means of education are the same thing: the end of education is that individuals continue learning and growing throughout life (MW 9: 107). Hofstadter suggests that this conflation of ends and means is confusing and misleading. In this section I address this criticism by focusing our attention on a key phrase in Dewey: "The very idea of education is a freeing of individual capacity in progressive growth directed at social aims" (MW 9: 105). What exactly does Dewey mean by "progressive growth"? What are the "social aims" by which growth is directed? How are social aims determined? Throughout this section, I argue that Dewey's view of progressive growth provides a compelling alternative to the fixed ends advocated by many of his critics, and taken up in new forms by current educational policy. 
Before proceeding, it is worthwhile to consider what Dewey means by an "end." Although deeply influenced by Hegel, Dewey became a life-long critic of any notion of telos or an absolute end for human affairs. In his educational thought, this required the ends of education be connected to students' lived experiences, means (methods), content (subject matter), and concrete social conditions. The relationship between means and ends, for Dewey, should not be understood as a dualism, but as a flexible continuum. In Democracy and Education, ends are defined in terms of intentional results: "[It] implies an orderly and ordered activity, one in which the order consists in the progressive completing of a process. Given an activity having a time span and cumulative growth within the time succession, an aim end means foresight in advance of the end or possible termination" (MW 9: 108) Here, ends become a part of a process, one stage in a continuum. Dewey actually preferred to use the term "ends-in-view" to capture this sense of process. This term keeps our attention on the ends of the particular task at hand and reminds us that ends are always provisional and changing throughout the course of educational experiences. Thus, ends-in-view are deliberately open ended; they represent a series of distinctions and criteria to measure and guide our practice. Later in the essay, I argue that Deweyan ends function as evaluative tools, allowing teachers, students and citizens to assess the ends for individual growth, vocational development, citizenship, and the general nature of education in a democratic society.

\section{Individual Ends}

Dewey offers the general principle of growth as the primary criteria to assess the educational value of experiences. Simply put, growth represents learning experiences that open up (rather than foreclose) opportunities for further growth. If a person gains a better sense of the meaning of experience and gains a greater sense of control over future experiences, they are better prepared to apply what they have learned flexibly in future situations. In other words, growth represents a form of learning that enables individuals to continue learning throughout their lives. This basic understanding of growth forms the basis for some key distinctions. Dewey holds that some experiences are noneducational, some are educational, and some are mis-educational. Noneducational experiences are simply unreflective. In routine experiences we do what is expected or customary without considering either the aims or meaning of experience.

The distinction between educational and mis-educational experience is central to understanding the broader ends of education. Experiences are mis-educative in the sense that we learn, but do not grow. By way of illustration, Dewey distinguishes between training (the routine mastery of skills unconnected to purposes) and education. "Trade education," at least in its worst forms, is a process of miseducation because it teaches students mindlessly to master specific skills or trades (MW 8: 119-120). A favorite example of Dewey's is a "gang of thieves" (MW 9: 88). We can imagine how the gang teaches a young recruit to become a thief. Through practice and study, our young thief becomes proficient at stealing, laundering loot, 
and maybe even leading her own gang. In the end, these "learning" experiences are mis-educative. While our thief is certainly becoming more skilled and knowledgeable, this learning limits the depth and breadth of her future experiences. Most importantly, the thief cannot interact freely with others, which severely diminishes her future possibilities for growth. In effect, there is learning but not in the service of growth. The key thing to remember is that this criterion of growth can be applied to any experience, practice, or curricula.

Dewey further qualifies the principle of growth by adding criteria to specify how an individual develops or grows. He offers two criteria-interaction and continuity-to assess educative experiences. The first criterion holds that educational experiences involve the deliberate act of experimenting in the world (MW 9: 142, 284; LW 13:31). As opposed to unthinking or nonreflective behavior, we learn when we consciously think through possible alternative courses of action and are attentive to consequences. The second criterion holds that isolated activities are not educational. Learning experiences must both connect to one's past life experience and open up future opportunities for growth. In this sense, connections between school and society-and between an individual's current experiences and possible future pursuits-become more explicit. Experiences should develop habits and attitudes that open up other lines of growth, and help an individual evaluate the quality of future experiences (LW 13: 23).

So far we have been discussing growth at a general level. At this point, there is no content or specific direction to growth. We can imagine that Hofstadter would argue that this principle of growth, without any discussion of content, is radically underdetermined. To respond, it's necessary to turn to the second clause of Dewey's definition of education-"progressive growth directed at social aims" (MW 9: 105).

\section{Social Ends}

As Hofstadter noted, Dewey's insistence that the ends and means of education are identical does not appear to provide any guidance in defining the larger purposes of education, or what Dewey would call "social aims" or "social ends" (MW 9: 104, 105). It is important to remember Dewey's earlier educational writings that call for a balanced consideration of the individual and social ends of education. In 1897, Dewey argued that we should educate individuals to have "an interest in community welfare, an interest ... in perceiving whatever makes for social order and progress, and for carrying these principles into execution" (EW 5: 63). This interest in community is framed as the "ultimate ethical habit" to which all other habits should be directed. While a rather noble idea, this statement runs right into Hofstadter's concern about how much guidance is required to determine these social ends. Even sympathetic interpreters such as Nel Noddings (1998) advance a similar critique: "Even as we admire and accept most of Dewey's advice on the conduct of education, we may worry about the criteria children will use to 'shape and direct' change. We know they must be social, but can the social be relied on to shape itself?" (p. 480). 
Dewey acknowledges this worry. In Democracy and Education, he considers the inherent tensions in any national system of education, detailing the competing roles played by nationalism, democracy, and other social aims. Dewey reminds us that any conception of the social is contextual. As he states, the "conception of education as a social process and function has no definite meaning until we define the kind of society we have in mind" (MW 9: 103). Dewey argues-agreeing with his critics, in a sense-that we need a clearer conception of the social as a function and test of education. He states: "This contradiction (for it is nothing less) between the wider sphere of associated and mutually helpful social life and the narrower sphere of exclusive and hence potentially hostile pursuits and purposes, exacts of educational theory a clearer conception of the meaning of 'social' as a function and test of education than has yet been attained" (MW 9: 104). Dewey's call for a clearer conception of the social begs for an answer. Yet, Dewey simply moves on from this point. Surprisingly, he does not offer a definition or sustained discussion of the social in Democracy and Education. He does say that "a true social group" involves "a sharing of purposes, a communication of interests" (MW 9: 9), but does not give any guidance to what these purposes might be. This seems like a glaring omission in Dewey's thought, particularly considering his claims that education is a social process, individuals are social beings, schools are social institutions, and the like.

I argue that the absence of a substantive discussion of the social is both an important omission and a surprising strength in Dewey's theory. In one sense, this omission reveals Dewey's radical antifoundational bent as a thinker. In failing to spell out the social, Dewey moves away from commonly accepted sources of authority such as tradition, philosophy, or God for determining the ends of education. In another sense, this omission reveals a different kind of political project. Dewey is attempting to chart a complicated path: trying to identify comprehensive social ends without resorting to the dangers of nationalism. These dangers remained in the background of Dewey's thinking about the social, and framed the nature and content of his response. Although Dewey did not offer a substantive definition of the social, I argue that we can — by looking more widely in his thinking — construct two possible responses to the "problem of the social." First, the very process of experimental inquiry gestures towards the definition of social ends. Second, Dewey offers democracy as the ideal and criteria to guide the definition of the social.

It is first important to notice the negative argument Dewey makes: social aims should not be determined externally to the processes of education. This, by way of contrast, focuses our attention on its opposite: the internal processes of education. This shift-from externally imposed definition to internally developing processesmeans that social aims are defined in and through educational practices, cooperative inquiry, and collective decision making. Moreover, we need to remember that Dewey's educational methods should always be understood in terms of specific situations. In conceiving education as a way of living and school as an embryonic community, learning is framed as a cooperative effort of acting and learning with others. By locating experimental inquiry within this cooperative context, problems 
are necessarily social problems. In effect, education is necessarily social and political; these dimensions are built into the very contours of experimental inquiry (Hildreth, 2009, p. 789).

While experimental inquiry is constitutively social, how does this inquiry take us beyond the social world we find ourselves in? What prevents inquiry from being parochial? As Dewey points out: "Since education is a social process, and there are many different kinds of societies, a criterion for educational criticism and construction implies a particular social ideal" (MW 9: 105). And democracy, not surprisingly, is this ideal. For Dewey, the social ideal of democracy is more than a form of government, but "conjoint communicated experience" where all citizens have a "clear consciousness of a communal life" (MW 9: 93; LW 2: 328). In other words, democracy is a way of life in which all citizens have a better understanding of the nature of communal life and therefore can make more enlightened collective decisions. In Democracy and Education he offers two criteria for educational criticism and construction:

1. The more numerous and more varied points of shared common interest and greater reliance upon the recognition of mutual interests as a factor in social control.

2. The freer interaction between social groups which brings about a change in social habits due the continuous readjustment of interacting with different groups. (MW 9: 92)

At first glance, these criteria do not appear to have much to do with education. The first seems to be a normative goal that mutual interests should guide collective decisions. The second gestures towards a sense of social life that is open, pluralistic, and interactive.

Upon closer inspection, we can see a much deeper argument. If we take seriously the injunction that education starts with experience and experience is social, the first criterion calls for a greater role for all actors (students, parents, teachers, administrators) in determining the conditions of learning and growth. Moreover, the second criterion holds that conditions for growth are enhanced through encountering difference; hence, the importance of variation and interaction. But the real pay-off for education comes when we combine the two criteria. Dewey states: "The extension in space of the number of individuals who participate in an interest so that each has to refer to his own action to that of others, and to consider the action of others to give point and direction to his own, is equivalent to breaking down those barriers of class, race, and national territory which kept men from perceiving the full import of their activity" (MW 9: 93). The aim of democracy and education is for people to develop mutual interests and gain a sense of the broader consequences of social interactions. Taken together, Dewey's criteria point towards ideal social conditions for individual growth. Mutual interest eliminates the artificial barriers between persons and different forms of experiences. This opens up greater possibilities for interaction, learning, and growth. 
Rather than defining social ends, Dewey gives us democratic criteria. This requires that educators, public officials, and citizens themselves do the difficult work of discussing, debating, and implementing visions of education in conversation with democratic ideals. Here, Hofstadter might say, "so far so good.” Educational actors should debate the ends of education. The problem is that growth-even when defined as more numerous points of shared common interest and freer interaction between social groups - is still too vague of an idea to address the difficult and technical questions of constructing a curriculum (see also Suppes, 1996). However, what Hofstadter seems to miss here is that Dewey's criteria do not help us create educational ends ex nihilo. Instead, criteria are used to assess both current and proposed educational goals, methods, and content. It is up to practitioners to do the hard work of applying the criteria to specific proposals and practices. To show how Dewey can be helpful in more specific terms, I turn to a discussion of commonly posed ends for education: work and citizenship.

\section{Two Specific Ends: Work and Citizenship}

A central point in the previous section is that the criterion of growth can be applied to any educational practice or institution. Dewey generally resisted giving us much detail on how this criterion applies to specific forms of schooling; to do so would violate his commitment to democratic ideals. In this section, I discuss two domains where Dewey gives us slightly more guidance: work and citizenship. These serve to illustrate how Dewey's criteria can be applied to specific ends for schooling.

\section{Work}

Dewey's position on the relationship between education and future employment is structured by a fundamental tension. ${ }^{4}$ On one hand, he is clear that one of the essential purposes of schooling is the preparation of young people for lives of meaningful work (MW 9: 126). Indeed, an essential end for education is to give all students the ability to be "masters of their own economic and social careers" (MW 9: 104). Given the fact that we spend the majority of our adult lives as workers, the challenge is to structure education and working conditions in ways conducive to individual growth. On the other hand, Dewey argues against conceiving of education as preparation for future living (MW 9: 59; LW 13: 28). ${ }^{5}$ Specifically, he believes that narrow training for a specific job ("learning to earn") is a cramped view of education (MW 10: 145). Not only is "trade training" inimical to growth, but "there is a grave danger that in insisting upon this end, existing economic conditions and standards will be accepted as final" (MW 9: 126). So the question looms large-how do you prepare young people for their future working lives in ways that are both vital for students and conducive to future growth? I argue that Dewey addresses this tension in two ways.

The first way centers on the adjective "meaningful." What makes work meaningful is actually more complex than it may first appear. Dewey argues that education can and should help individuals understand the larger social significance 
of their paid work. Thus, mind-numbing physical labor can be meaningful if the worker understands the role of her activities in the production process and the role of the company in the larger economy. This may seem a like a tepid consolation. Understanding the larger social processes of being a line cook at McDonald's would probably make the work even more depressing. Dewey believes, however, that understanding the larger social and economic processes changes one's attitude towards paid work. It allows us to see connections between our work and its consequences and therefore better enables us to learn and grow.

Here, we can see how Dewey advocates learning through-although not for-occupations. Dewey and his collaborators set up occupations as "articulating centers" of the Laboratory School. Occupations played three roles in the Laboratory School: they organized studies, helped students understand the larger meaning of future work, and exposed students to a variety of possible vocations. Dewey offers a special definition of occupations as "modes of activity which reproduce, or run parallel to, some form of work carried on in social life" (MW 1: 92). These activities were designed to be closely related to the everyday world of students; as such, they focused on the occupations children would have encountered around the home: sewing, cooking, and so on. The aim of learning through occupations didn't involve mastering tools, acquiring skills or producing objects. Rather, through engaging in occupations, the child is given "intellectual responsibility for selecting the materials and instruments that are most fit, and give(n) an opportunity to think out his own model and plan of work, led to perceive his own errors, and find out how to correct them" (MW 1: 92). Thus, occupations are academically rigorous, requiring students to "put maximum consciousness into whatever is done" (MW 1: 93).

More importantly, these occupations mirror larger social, historical, and industrial processes. In this sense, students learn about industrial processes through simplified constructive activities. Rather than just practicing craftwork, Dewey argues that "we must conceive of [occupations] in their social significance, as types of processes by which society keeps itself going" (MW 1: 10). Students not only learn how to weave, but "learn the progress of mankind in history" through investigating the science of fibers, the history of development in use and manufacture, and the cultural dimensions of clothing (MW 1,: 14, 15). Thus, occupations enlarge experience through an examination of - and a working through-its geographic, artistic, literary, scientific, economic, and historical elements. Through investigating how society developed its means of production, students gain an intellectual and practical understanding of how society came to be. Against Hofstadter's calls for specialization, education through occupations reinforces the idea that "all studies arise from aspects of the one earth and the one life lived upon it. We do not have a series of stratified earths. When the child lives in varied but concrete and active relationships with the common world, his studies are naturally unified" (MW 1: 54). Such an education gives students an expanded notion of the political, economic, and social significance of their future work and the flexibility of intelligence needed to adjust to rapidly changing conditions. 
The second way Dewey addresses the tension between training and preparation for meaningful work is through a reconsideration of vocation. Here, Dewey draws on earlier religious traditions of vocation to mount an argument against what was then called vocational, industrial, or trade education. ${ }^{6}$ Dewey's innovation is to return to the older sense of vocation as "a calling" and then reconstruct it as plural, advancing the idea that people have many different callings. Schooling should help individuals discover and develop a variety of "intelligently effective" vocations (MW 9: 317). This notion of vocation contrasted with models at the time that pushed students, often on the basis of IQ tests, towards training for one line of paid employment. Recognizing that human beings are always more than their paid occupations, Dewey states, "we must avoid limitation of conception of vocation to the occupations where immediately tangible commodities are produced" (MW 9: 317).

The term "vocation" signals that a particular constellation of interests and habits are an integral part of who we are. To put it differently, we could not be ourselves, if we are not following our calling. When we are living our vocation, we both lose and find ourselves in that particular object or activity. "In fact," Dewey continues, "self and interest are two names for the same fact; the kind and amount of interest actively taken in a thing reveals and measures the quality of selfhood which exists (MW 9: 362). This continuous development of “interesting” experiences, of "losing and finding oneself" in a particular activity, coalesces into a sense of vocation. Vocation, therefore, refers to the "the active moving identity of the self with a certain object" (MW 9: 362). When we are living our vocation, we find meaning in our (paid or unpaid) work.

Here we can see how the criterion of individual growth can be applied to the specific end of work. Because we spend most of our lives working, continued growth is best achieved when an individual's vocational calling and paid work align. However, the fact of rapid economic change means that particular jobs, industries, and skills may become obsolete. Thus, Dewey advocates the development of a wide array of vocational interests (MW 9: 317). This diversity of vocations helps individuals develop flexible habits of inquiry and action. An expanded sense of interests and expertise allows individuals to be better positioned to adjust, adapt, and thrive in a society marked by constant and rapid change. Even if they were affected by the inevitable changes in economic conditions, this enlarged sense of meaning and flexibility means that they would not be at the mercy of a single industry or trade. This, in the end, is the best chance individuals can have greater control over their economic lives.

\section{Citizenship}

Dewey's pluralist conception of vocation overlaps with his normative understanding of citizenship. It is important to remember that Dewey consistently refused to treat education for citizenship as a distinct subject matter. I agree with Sandra Rosenthal (1993) and others that this is not an omission, but rather an indication that Dewey's entire philosophy of education can be read in terms of citizenship. In addressing a meeting of teachers, Dewey said as much: "I take it for granted that we all admit 
that, so far as our common school system of education is concerned, the main business must be to prepare the boys and girls and young men and women who come to these schools to be good citizens, in the broadest sense" (MW 15: 158). So what exactly is good citizenship, in this "broadest sense"? Dewey is clear that we should not conceive citizenship in the narrow sense as the "capacity to vote intelligently, a disposition to obey laws, etc." (EW 5: 58). In contrast to the "standard end" of civic education as training future citizens to be more informed voters, Dewey calls for a more encompassing education for citizenship that will "enable the child to recognize all his social relations and to carry them out" (EW 5: 58). For Dewey, a citizen is not merely a voter, but a family member, employee, friend, member of associations, and resident of a particular community (to name a few possible dimensions). He therefore advocates that young people "develop the power of observation, analysis, and inference with respect to what makes up a social situation and the agencies through which it is modified" (EW 5: 73). Here we can see the overlap between Dewey's plural conception of vocation and citizenship. If we read citizenship in vocational terms, it is a distinct mode of being in which an individual hears the political call of the world and possesses the critical and political habits to respond.

Thinking in terms of Hofstadter's critique, this conception of citizenship provokes a few questions: What exactly would this ideal of citizenship look like? And, is this definition of citizenship so broad that it lacks substantive content? I argue that, from the few places that Dewey explicitly discusses citizenship, we can glean possible ends for citizenship education. Two possibilities stand out.

First, Dewey argues that an important aim for citizenship education is to develop political judgment (MW 4: 290). Good judgment is based on a critical understanding of how political, social, and economic systems actually work. Dewey claims that schools have over-emphasized civic knowledge-learning about the institutions of government, how a bill becomes a law, and so on. Standard civics exclusively focuses on processes and institutions rather than looking how government actually works. He goes onto say, "I don't think we can pride ourselves upon really preparing our student body to make good citizens from a political point of view. We are preparing a somewhat passive body of citizens who will be managed and exploited either by political machines, or in reaction against them, by demagogues and agitators" (MW 15: 163). This view directly challenges the "social efficiency" movement in Dewey's day and its emphasis on obedient citizenship. This critical vision of citizenship education calls for not only examining the power of government, but investigating the power behind government, especially the connections between government and industry (MW 15: 160, 163). Interestingly, in this vein, Dewey advocates the study of economic history rather than political history (MW 9: 223-224). This is not just knowledge for the sake of knowledge. Rather it is knowledge that will lead to better judgment in evaluating political problems and plans (MW 15: 163).

The second aim focuses on developing capacities to effect social and political change (MW 9: 93). This takes us back to the democratic criteria discussed in 
the previous section. Dewey argues that a democratic society should be interactive, diverse, and flexible. Thus, he urges individuals to join and share in the direction of groups in which they belong (including the workplace). These groups represent "democracy as a way of life" on a small scale and provide the opportunity to "practice" the skills of democratic life-communication, deliberation, negotiation, and problem solving. Dewey hopes that participatory processes, in all forms of social life, will provide the conditions for individual growth in harmony with the common interests of the group.

While groups represent a learning opportunity, as it were, Dewey is acutely aware that groups can sometimes be undemocratic or even antidemocratic. This leads to Dewey's second educational criterion of free and full interaction between groups (a standard that the band of thieves would not meet). Dewey believes that this interaction between groups has both an educative and democratic function. As noted above, broad interaction between groups helps to break down barriers and therefore opens up further opportunities for growth. By seeing how the consequences of actions of one group affect other groups or the larger public, individuals can learn the broader public meanings of their actions. This, Dewey believes, is a key part of developing "good citizens." He states that "a good citizen finds in his conduct of a political group enriching and enriched by his participation in family life, industry, scientific and artistic associations. There is a free give-and-take: fullness of integrated personality is therefore possible of achievement, since the pulls and responses of different groups reënforce one another and their values accord" (LW 2: 328). Here we see the specific content to Dewey's early articulation of citizenship in its broadest sense. It is not just citizenship across social roles, but it is a particular political orientation to the world that is embedded in and across roles.

Both of these inquiries - into the specific ends of work and citizenship-offer examples of how we might read within (and across) Dewey to reconstruct ends in expansive and democratic terms. Dewey deliberately leaves the social ends of education open, but, through his discussion of citizenship, shows how everyday citizens might develop the capacities to determine them collectively. Here, too, we can see how vocational and civic ends overlap: both stress diversity and flexibility; both aim to provide individuals a sense of who they are in the world and a sense of how the world works. In this sense, they both give individuals greater control over their working lives as well as the collective conditions of existence. In a world defined by constant flux, Dewey constructs ends for work and citizenship that help individuals understand, adapt to, and possibly direct social change.

\section{Conclusions}

Dewey's ideal of education advances a particular vision for an "educated individual" and a democratic society. This individual has developed flexible habits of critical inquiry to continue learning throughout their lives. They have a wide variety of interests and vocations. This flexibility and breadth allows individuals to have greater control over their economic lives and be more effective participants 
in democratic life. In this conclusion, I respond to Hofstadter, and discuss in more depth the contribution Dewey's educational thought might make to contemporary discussions of educational ends.

Recall that Hofstadter sharply criticized Dewey for failing to provide definite ends for education. Defining just what these definite ends might mean takes us to the crux of the matter. As the previous section details, Dewey provides criteria and democratic processes for citizens (students, teachers, parents, administrators, etc.) to determine ends for education. The ends that Dewey proposes are open; they remain defiantly indefinite. So, strictly speaking, Hofstadter is correct: Dewey does not supply definite ends. I argue that Dewey's refusal to name definite ends represents his radicalism. Dewey leaves ends open because he trusts citizens to determine the social ends and implement educational programs accordingly. Here, Dewey poses the question of ends as ineluctably political. The ends of education must be determined at every level of teaching and learning, through collective deliberation and possibly political struggle.

However, Hofstadter contends that Dewey's undefined ends-in the hands of progressive educators-proved confusing and deleterious for American education. For Hofstadter, growth is not only a poor metaphor for education, but also encourages educators to place the interests of the child over society, curriculum, and tradition. This secondary point raises a more important question, in my view, especially when reframed around what Dewey does offer: not ends, but criteria to guide our ends. In this vein, I believe that Hofstadter's criticism might be valuably reframed in the following question: Does Dewey provide sufficient guidance so that citizens can determine their own ends and construct educational practices, systems, or institutions accordingly?

I argue that Dewey's criteria for assessing growth, democratic control, and social interaction are clear. On a basic level, these criteria can be applied to any educational practice or program, from formal schooling to informal learning. It is challenging, but not impossible, to apply the criterion of growth in a school setting. Indeed, most efforts at assessment seek to "measure" learning. Measuring growth, however, requires both careful attention to individual students and attention to their learning over time. It also expands our view from only looking at particular activities or subjects-reading for instance-to how these activities or subjects affect broader domains of individuals' lives. For Dewey, continued debate-and democratic control-over curriculum will always be better than posing any final standards or rigid developmental logic. This stance, however, does not mean that there are no ends for curriculum. The criteria of growth, democratic control and interaction simply ask for more careful design, flexibility, monitoring, adjustment, and judgment in developing and implementing curriculum at every level.

This vision of democratic control, deliberation and evaluation is increasingly far removed from education reform and policy today. While it is outside the scope of this essay to present a full-scale Deweyan analysis of current policy, it is possible to gesture towards questions such an analysis would address (see Finnell-Gudwien, 
2006). Considering increasingly narrow understandings of academic achievement, Dewey might urge us to ask a series of larger questions: how do these ends connect with concrete social conditions, in specific classrooms, schools and communities? How are these ends connected with the means of education; that is, with approaches of teaching and learning in actual classroom environments? Even if we can agree on academic ends-in-view, how might they be measured in ways that are not disconnected from the judgment and authority of teachers and local school communities? Likewise, how can we support school reform efforts that support and strengthen the ability of everyday citizens to deliberate about - and actively determine-educational ends in their own contexts?

In this spirit, increasingly technocratic reforms may provide an opportunity to question the ends of education, and how they are determined. Dewey does notas Hofstadter notes-provide "definite ends" for education. This is not an omission. Instead of posing definite ends for education, Dewey believes in the capacities of educational actors to determine their own ends. This belief is not blind. Dewey outlines how individuals might develop civic habits and capacities to engage in the coconstruction of social ends. Moreover, he stresses criteria- of growth, democratic control, and social interaction - that citizens might collectively use to evaluate and construct educational practices and goals that are both connected to local circumstances and directed towards broader social aims. Most importantly, for Dewey, neither philosophers, nor policy experts alone, can determine the ends of education. The question of ends-however complex and difficult-remains a question for the diverse stakeholders at each level of education practice, from classrooms to state departments of education. ${ }^{7}$ Only through continued conversation about possible ends and careful attention to consequences can we approximate Dewey's ideal of democratic education.

\section{Acknowledgments}

I am grateful to friends and colleagues for comments, criticisms, and advice on earlier drafts of this essay. These include James Farr, Alison Kadlec, Amit Ron, Emanuele Saccarelli, and Terri Wilson. I also want to thank David Granger and the anonymous reviewers at Education and Culture. Barbara Levine and James Downhour at the Center for Dewey Studies at Southern Illinois University-Carbondale provided invaluable research assistance.

\section{Notes}

1. To be more precise, Dewey argues that philosophers cannot conceive of ends outside a concrete social setting and then impose them on a particular educational practice. Dewey rejects any ultimate end "to which education is subordinate" (MW 9: 107). He also rejects any ends outside of or external to the educational process (MW 9: 116). As he states, "The philosophy of education neither originates nor settles ends. It occupies an intermediate and instrumental or regulative place. Ends actually reached, consequences that actually accrue, are surveyed, 
and their values estimated in the light of a general scheme of values" (LW 5: 29). Ends always emerge from - and must be tied back to-concrete situations, processes and practices.

2. Dewey has been repeatedly critiqued for his naiveté on this point (see Cohen, 1998; Kaufmann-Osbourn, 1984). These critics argue that Dewey relies too much on education as a vehicle for social progress and fails to take existing social structures into account. There is some credence to these criticisms. First, Dewey does not articulate exactly how schools should or could bring about reform. We are left with the assumption that if given a progressive education, students would become reformers in their adult lives. Such adults would see the social significance of their work, be able to continue learning through their work, and have flexible habits to adjust to new situations. Thus, like many forms of participatory theory, the onus for change is placed on the shoulders of students, as future citizens. In this vein, Westbrook (1991) criticizes the Dewey School for "preparing students for life in a society that did not exist" (p. 111). It is important to note that Dewey recognized the difficulties involving school reform at an early stage in his career. In the same year Dewey wrote School and Society, he also wrote an essay titled "The Educational Situation." Here Dewey gives a detailed analysis of the difficulty of reforming schools themselves (MW 1: 269). This analysis reveals that Dewey was aware that the relationship between schools and social reform was more complicated. Additionally, by the mid-teens his optimism about schools as the sole agents of social progress had dampened. Perhaps chastened by his experiences with the Laboratory School, the later Dewey saw schools as one of many possible sources of change.

3. Craig Cunningham (1994) presents a sophisticated analysis of how the concept of aims evolved in Dewey's educational thought. He agrees with Hofstadter on the view that Dewey's early educational writings presupposed a "'pre-established harmony' between the individual and society" (p. 6). While I agree that Dewey's early work was still infected with Hegelian idealism, Cunningham misses the vital role that democracy plays in determining educational ends at all levels of practice.

4. In this section, I use the Deweyan terms work, occupation, and vocation. Because Dewey did not always use these terms in consistent ways, I define them here in the following way. Work "signifies purposeful activity ... that is subordinated to an external result . .. [and defined by a] a longer course of activity"(MW 9: 212). I use Dewey's pedagogical definition of occupation in School and Society as "a mode of activity on the part of the child which reproduces, or runs parallel to, some form of work carried on in social life" (MW 1: 92). For vocation, I draw primarily on Democracy and Education, where Dewey discusses vocation as a calling, "a direction of life activities as renders them perceptibly significant to a person and also useful to his associates" (MW 9: 316).

5. The relationship between education and preparation is complex. In Democracy and Education, Dewey rejects traditional conceptions that understand education as preparation. The problem with preparation is that it imposes external ends on educational processes. In "My Pedagogic Creed," Dewey offers a qualification on preparation: "it is impossible to foretell definitely just what civilization will be twenty years from now. Hence it is impossible to prepare the child for any precise set of conditions. To prepare him for the future life means to give him command of himself; it means so to train him that he will have the full and ready use of all his capacities; that his eye and ear and hand may be tools ready to command, that his judgment may be capable of grasping the conditions under which it has to work, and the executive forces be trained to act economically and efficiently. It is impossible to reach this sort of adjustment save as constant regard is had to the individual's own powers, tastes, and interests-say, that is, as education is continually converted into psychological terms" (EW 5: 66). 
6. Kliebard (1995) argues that that one of Dewey's strengths and weakness in these debates was exactly this appropriation and reconstruction of existing concepts and theories.

7. David Labaree (1997) makes a similar point: "I argue that the central problems with American education are not pedagogical or organizational or social or cultural in nature but are fundamentally political. That is, the problem is not that we do not know how to make schools better but that we are fighting among ourselves about what goals schools should pursue. Goal setting is a political, and not a technical, problem. It is resolved through a process of making choices and not through a process of scientific investigation. The answer lies in values (what kind of schools we want) and interests (who supports which educational values) rather than apolitical logic" (p. 40).

\section{References}

Ancess, J., \& Allen, D. (2006). Implementing small theme high schools in New York City: Great intentions and great tensions. Harvard Educational Review, 76(3), 401-416.

Bandeira de Mello, V., Blankenship, C., and McLaughlin, D. H. (2009). Mapping state proficiency standards onto NAEP scales: 2005-2007 (NCES 2010456). Washington, DC: National Center for Education Statistics, Institute of Education Sciences, U.S. Department of Education.

Bloom, A. (1987). Closing of the American mind. New York, NY: Simon and Schuster. Bowles, S., \& Gintis, H. (1976). Schooling in capitalist America: Educational reform and the contradictions of economic life. New York: Basic Books.

Cohen, S. (1998). John Dewey's problem. Elementary School Journal, 98(5), 479-493. Cunningham, C. (1994, April). Ideal ends: John Dewey's later vision for education. Paper presented at the American Educational Research Association, New Orleans, LA.

Dewey, J. (1967-1972). John Dewey: The early works, 1882-1898. Volumes 1-5 (Jo Ann Boydston, Ed.). Carbondale: Southern Illinois University Press.

___. (1981-1990). John Dewey: The later works, 1925-1953. Volumes 1-17. (Jo Ann Boydston, Ed.). Carbondale, IL: Southern Illinois University Press.

_-_. (1976-1983). John Dewey: The middle works, 1899-1924. Volumes 1-15. (Jo Ann Boydston, Ed.). Carbondale, IL: Southern Illinois University Press.

Finnell-Gudwien, C. (2006). A democratic view of "No Child Left Behind." Education and Culture, 21(3), 3-11.

Freire, P. (1970). Pedagogy of the oppressed. (Myra Bergman Ramos, Trans.). New York: Continuum.

Greene, M. (1988). The dialectic of freedom. New York, NY: Teachers College Press.

Hildreth, R. W. (2009). Reconstructing Dewey on power. Political Theory, 37(6), 780-807.

Hirsch, E. D. (1987). Cultural literacy: What every American needs to know. New York: Vintage Books.

Hirsch, E. D. (1996). The schools we need. New York: Anchor.

Hook, S. (1980). Introduction. In J. Boydston (Ed.), The collected works of John Dewey, The middle works of John Dewey, 1899-1924, Volume 9: 1916, Democracy and education (pp. ix-xxiv). Carbondale, IL: Southern Illinois University Press. 
Hook, S. (1959). The ends and content of education. Daedalus, 88(1), 7-24.

- _ . (1944). The ends of education. Journal of Educational Sociology, 18(3), 173-184.

Hofstadter, R. (1963). Anti-intellectualism in American life. New York: Vintage.

Kandel, I. L. (1943). The cult of uncertainty. New York: Macmillan.

Kaufman-Osborn, T. (1984). John Dewey and the liberal science of community. Journal of Politics, 46(4), 1142-1165.

Kliebard, H. (1995). The struggle for the American curriculum: 1893-1950. New York: Routledge.

Labaree, D. (1997). Public good, private goods: The American struggle over educational goals. American Educational Research Journal, 54(1), 39-81.

Menken, K. (2006). Teaching to the test: How No Child Left Behind impacts language policy, curriculum, and instruction for English language learners. Bilingual Research Journal, 30(2), 521-546.

McNeil, L. (2005). Faking equity: High-stakes testing and the education of Latino youth. In Valenzuela, A. (Ed.), Leaving children behind: How "Texas-style" accountability fails Latino youth (pp. 57-111). Albany, NY: SUNY Press.

Noddings, N. (1998). Thoughts on John Dewey's ethical principles underlying education. Elementary School Journal, 98(5), 480-488.

Ravitch, D. (2000). Left back: A century of failed school reforms. New York: Simon and Schuster.

_-_- (2001). Education and democracy. In Diane Ravitch and Joseph P. Viteritti (Eds.), Making good citizens (pp.15-29). New Haven, CT: Yale University Press.

- - - (2010a). The death and life of the great American school system. New York, NY: Basic Books.

- - - (2010b). Why public schools need democratic governance. Phi Delta Kappan, 91(6), 24-27.

Ready, D., \& Lee, V. E. (2008). Choice, equity, and the schools-within-schools reform. Teachers College Record, 110(9), 1930-1958.

Rosenthal, S. (1993). Democracy and education: A Deweyan approach. Educational Theory, 43(4), 377-389.

Rothstein, R. \& Jacobsen, R. (2006). The goals of education. Phi Delta Kappan, 88(4), 264-272.

Suppes, P. (1996). The aims of education. In Alvin Nieman (Ed.), Philosophy of education 1995 (pp.110-126). Urbana, IL: Philosophy of Education Society.

Westbrook, R. (1991). John Dewey and American democracy. Ithaca, NY: Cornell University Press.

Wilson, T. (2010). Between public and private: parents and distinctive schools of choice. (Unpublished doctoral dissertation). Columbia University, NY.

R. W. Hildreth is Assistant Professor of Political Science at Southern Illinois University - Carbondale.

E-mail: roudy@siu.edu 